\title{
A synthesis of ferrocenyl dihydrocoumarin and ferrocenyl dihydroquinolin-2(1H)-ones
}

\author{
Wen-Feng Wang,* Jia Fan, Can-Zhou Luo, Yao-Feng Yuan and Yong-Fan Zhang \\ College of chemistry and chemical engineering , Fuzhou University, Fuzhou 350108, Fujian \\ Province, China \\ E-mail: wangwf@fzu.edu.cn (W.-F.,W.)
}

DOI: http://dx.doi.org/10.3998/ark.5550190.0012.b10

\begin{abstract}
A series of phenols have been used to react with ferrocenyl cinnamic acid, and the results of ${ }^{1} \mathrm{H}$ NMR and crystal structures have shown that only resorcinol and 2-naphthalenol can get ring closure products, while the others only get esterified products. This is because resorcinol and 2naphthalenol have higher electronic density in ortho-site of hydroxyl than other phenols used in this work. Ten ferrocenyl dihydroquinolin-2(1H)-ones are synthesized by hydroarylation of ferrocenyl acrylic amides in the presence of TFA, and an interpretation is also given to the experimental fact that strong acid can not catalyze hydroarylation of acrylic anilides to dihydroquinolones.
\end{abstract}

Keywords: Dihydrocoumarin, ferrocenyl, dihydroquinolin-2(1H)-ones, DFT

\section{Introduction}

4-Aryl-3,4-dihydrocoumarins are of synthetic interest because they are present in a number of natural molecules, such as 4-aryl-3,4-dihydrocounmarins (neoflavonoids), ${ }^{1}$ complex falvonoids ${ }^{2}$ and tannins. ${ }^{3}$ Also, many compounds containing 3,4-dihydrocoumarins rings possess important biological activities; for example, inhibitors of aldose reductase, ${ }^{4}$ protein kinases ${ }^{5}$ and antiherpetic. ${ }^{6}$ In 2008, detailed structure-activity relationships on splitomicin derivatives and their inhibition of recombinant Sirt2 were presented by Jung. ${ }^{7}$ 3,4-Dihydroquinolin-2(1H)-one skeletons are rarely found in naturally occurring substances, but they possess varied and powerful biological properties $;{ }^{8-9}$ for example, they have been proposed as a pharmacophore for norepinephrine transporter(NET) inhibition. ${ }^{10}$

At present, the dihydrocoumarin ring is usually synthesized from phenol and cinnamic acid derivatives. ${ }^{11-13}$ This reaction is an atom-economic synthesis and includes esterification and F-C alkylation two steps ( Equation 1). 


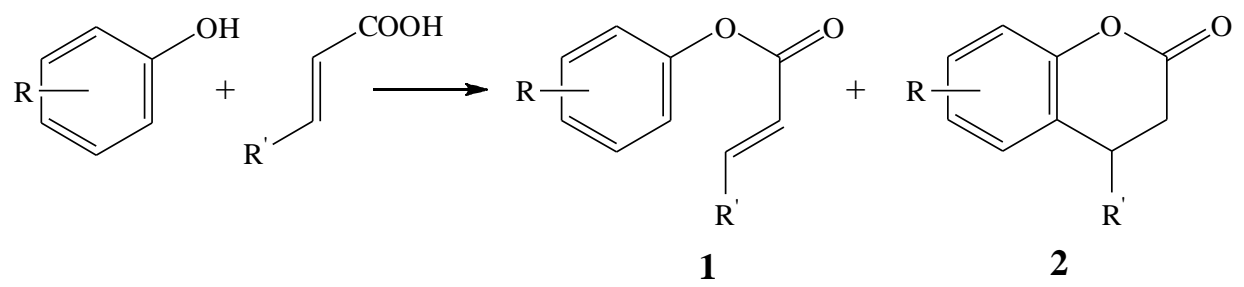

In many cases, esterified product $\mathbf{1}$ is the main product for Eq. 1. These cases are when (1) the reaction proceeds at low temperature ${ }^{14}$ (2) the acidity of catalyst is not strong enough, ${ }^{15}$ (3) there is a strong electron-withdrawing substituent in phenol ring ${ }^{16}$. The effect of spatial obstacle of R' for ring closure is different with the use of different catalyst. Gunnewegh[11] used solidacid (zeolite H-Beta) as catalyst and found that crotonic acid ( $\mathrm{R}^{\prime}=$ methyl) did not react to obtain ring closure product 2 . Jagdale $^{17}$ and Kitamura ${ }^{13}$ used toluene-4-sulfonic acid or TFA as catalysts, and found substituted cinnamic acids ( $\mathrm{R}^{\prime}=$ phenyl) could react with resorcinol to obtain ring closure product 2 easily. In addition, which step proceeds first is still a question in dispute. Ferrocenyl is much bigger than phenyl and it is unknown whether ferrocenyl acrylic acid can react with phenol to obtain dihydrocoumarin. Ferrocenyl has redox activity and it has been used in some anti-tumor drugs ${ }^{18}$. It is possible that dihydrocoumarin, which attaches ferrocenyl, will increase its biological activity.

3,4-Dihydroquinolin-2(1H)-one can be prepared in good yield in the presence of acid catalyst by coupling anilines with cinnamic acids prior to hydroarylation ${ }^{19-20}$. The synthesis of dihydroquinolin with attached ferrocenyl has never been reported. It is also unknown whether ferrocenyl will hold back the ring closure of acrylic anilides to dihydroquinolin. In addition, if the two ortho positions of an amide group are different, the position which will take place in the ring closure is still a question. In this paper, we use a series of phenols to react with ferrocenyl acrylic acid and want to test whether ferrocenyl can affect ring closure. In order to test the electronic effect on F-C alkylation of acrylic anilide to 3,4-Dihydroquinolin-2 $(1 H)$-one, we also synthesize a series of 3,4-Dihydroquinolin-2(1H)-one.

\section{Results and Discussion}

\section{Synthetic route}

The synthetic route of this paper is shown as in Scheme 1.

\section{The choice of acid catalyst}

When ferrocenyl acrylic acid 5 reacts with various phenols to generate $\mathbf{6}$ and $\mathbf{7}$, the choice of acid catalyst is important. Seven acid catalysts have been used as catalysts: $\mathrm{TsOH}\left(\mathrm{p}-\mathrm{CH}_{3}-\mathrm{C}_{6} \mathrm{H}_{4}-\right.$ $\left.\mathrm{SO}_{3} \mathrm{H}\right)$, TFA $\left(\mathrm{CF}_{3} \mathrm{COOH}\right), \mathrm{c}-\mathrm{H}_{3} \mathrm{PO}_{4}(85 \%)$, c- $\mathrm{HCl}(37 \%)$, PPA, c- $\mathrm{H}_{2} \mathrm{SO}_{4}(98 \%)$ and $\mathrm{H}_{2} \mathrm{SO}_{4} / \mathrm{C}(\mathrm{c}-$ $\mathrm{H}_{2} \mathrm{SO}_{4}$ loaded by activated carbon). Only concentrated sulfuric acid $(98 \%)$ can catalyze the 
reaction well. In ring closure of 9 to $\mathbf{1 0}$, the yield is very low when c- $\mathrm{H}_{2} \mathrm{SO}_{4}$ is used as catalyst, but TFA can catalyze the reaction well.
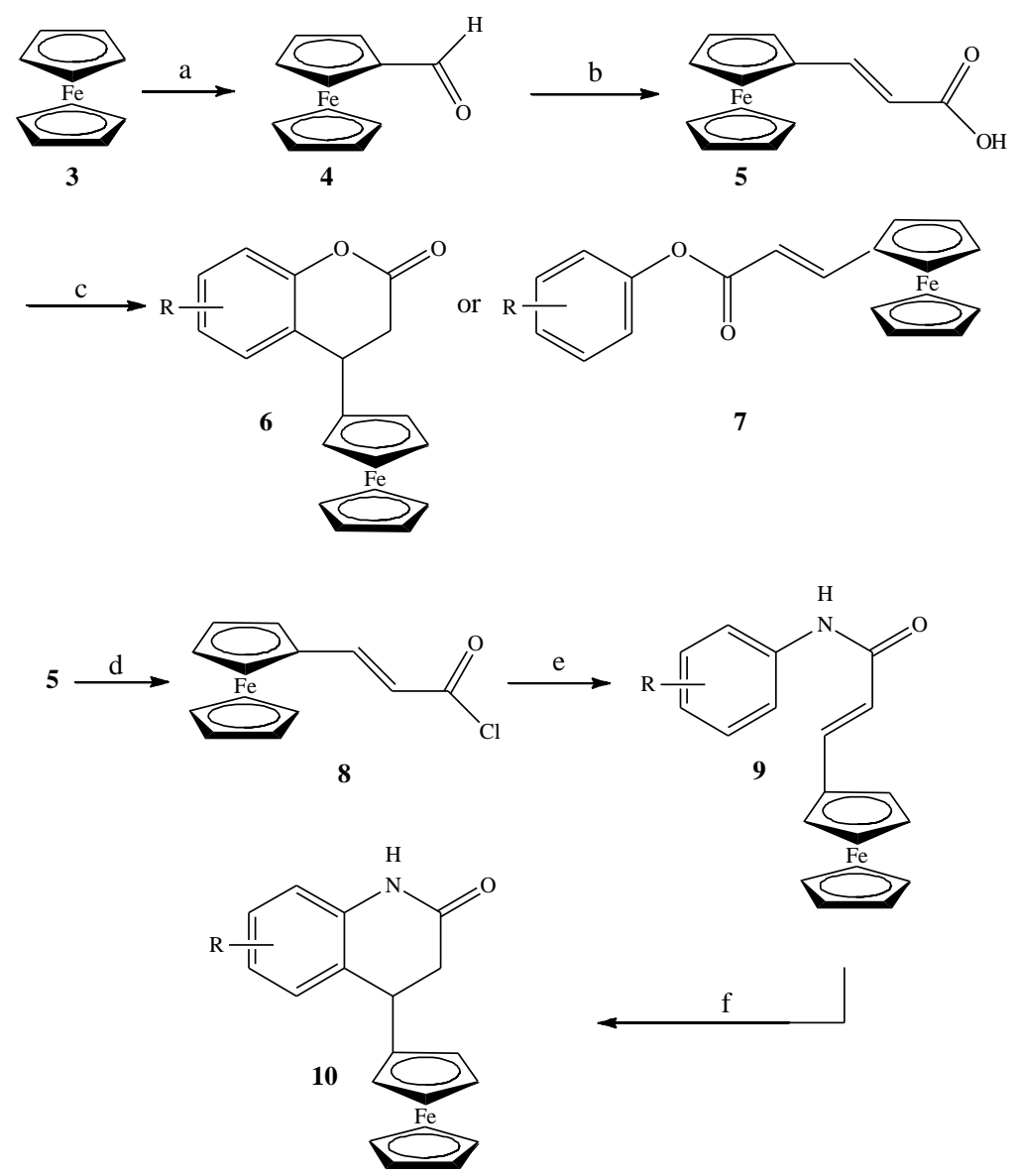

(a) $\mathrm{PhN}\left(\mathrm{CH}_{3}\right)$-CHO, $\mathrm{POCl}_{3}$ (b) Propanedioic acid, Pyridine (c) Phenol, $\mathrm{H}^{+}$(d) $(\mathrm{COCl})_{2}(\mathrm{e}) \mathrm{R}\left(\mathrm{C}_{6} \mathrm{H}_{4}\right) \mathrm{NH}_{2}$ (f) $\mathrm{TFA}\left(\mathrm{CF}_{3} \mathrm{COOH}\right)$

\section{Scheme 1}

\section{Esterified product (7) and ring closure product (6)}

Seven phenols have been used to react with $\mathbf{5}$ in this paper; some of these can form ring closure product 6 , while the others can only form esterification product 7 . We have never obtained products that include both 6 and 7. The structures of phenols and their corresponding products are shown in Table 1. 
Table 1. The reaction of various phenols with ferrocenyl acrylic acid

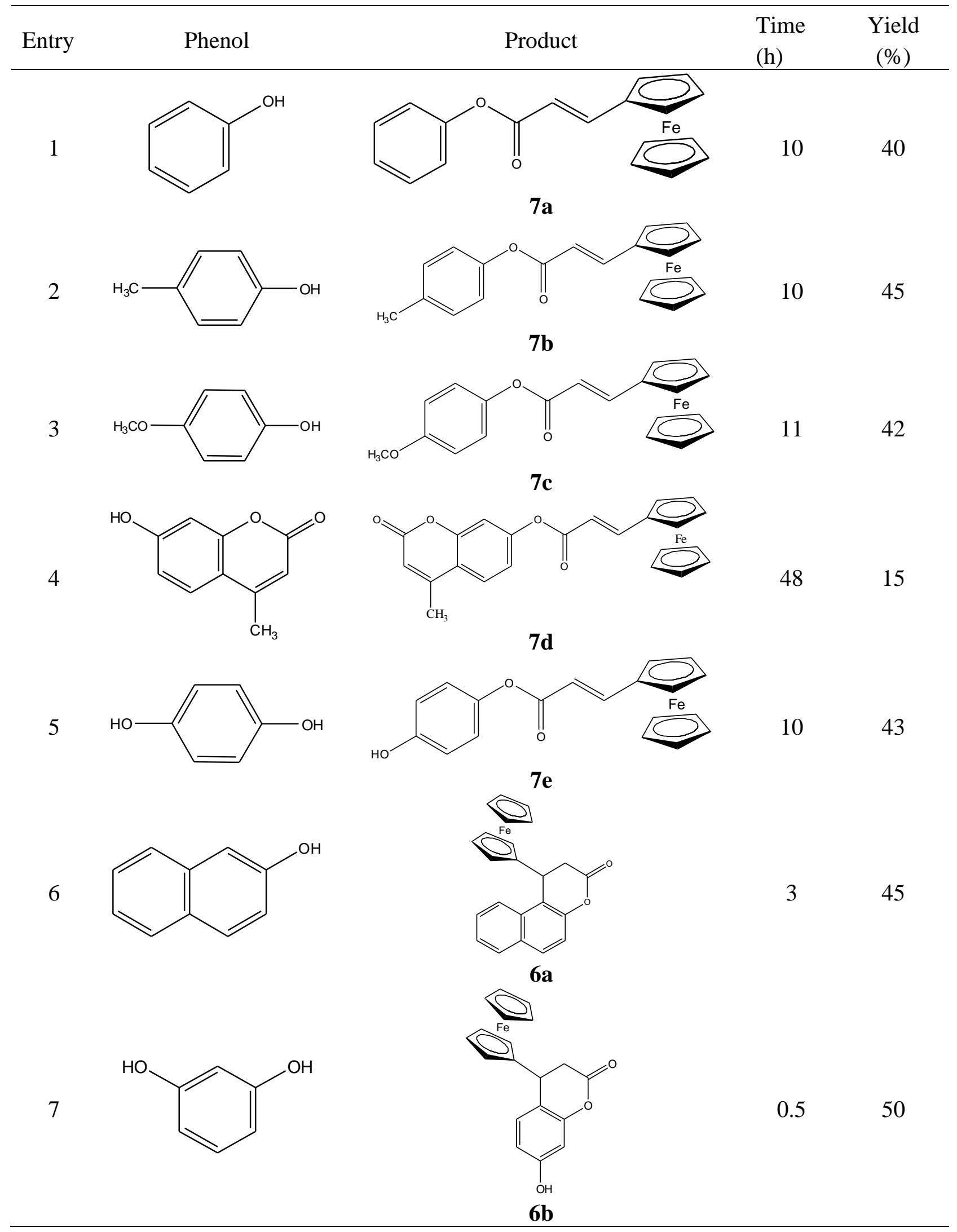




\section{Why can some phenols lead to ring closure product?}

At first, we used phenol, p-cresol, 4-methoxyphenol, umbelliferone and 2-naphthalenol to react with ferrocenyl acrylic acid $\mathbf{5}$ and found that only 2-naphthalenol produces ring closure product 6a, while the others only obtain esterified product 7a 7d. Quantum chemistry calculations show that 2-naphthalenol has the highest $\pi$ electron density at the ortho-position of hydroxyl of all phenols we used. See Table 2.

Table 2. The $\pi$ electron population number in ortho-site of hydroxyl of various phenols

\begin{tabular}{cccccc}
\hline Phenols & Phenol & p-Cresol & $\begin{array}{c}\text { 4-metho } \\
\text { xyphenol }\end{array}$ & $\begin{array}{c}\text { Umbelli } \\
\text { ferone }\end{array}$ & $\begin{array}{c}\text { 2-naphth } \\
\text { alenol }\end{array}$ \\
\hline Population number & 1.063 & 1.056 & 1.049 & 1.064 & 1.102 \\
\hline
\end{tabular}

According to table 2, we postulate that phenols which have a large $\pi$ electron density will obtain the ring closure product when it reacts with ferrocenyl acrylic acid. So, the $\pi$ electron density at the ortho-site of the hydroxyl of hydroquinone and resorcinol were calculated with their values being 1.051 and 1.100, respectively. Experimental result show that resorcinol delivers ring closure product $\mathbf{6 b}$ (by NMR) and hydroquinone delivers the esterified product 7e (by NMR and crystal structure). This experiment suggests that our postulate is correct.

\section{Crystal structures}

Crystal structures for $\mathbf{6 a}, \mathbf{7 a}, \mathbf{7 d}, \mathbf{7 e}$ were obtained in this research. The molecular structures that come from these crystal structures are shown in Figure 1; the crystal structures can be found in CIF files.

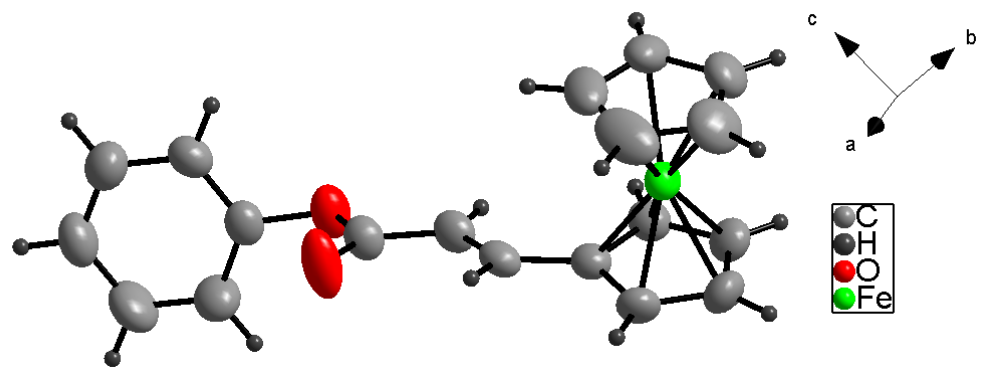

7a (CCDC: 727727)

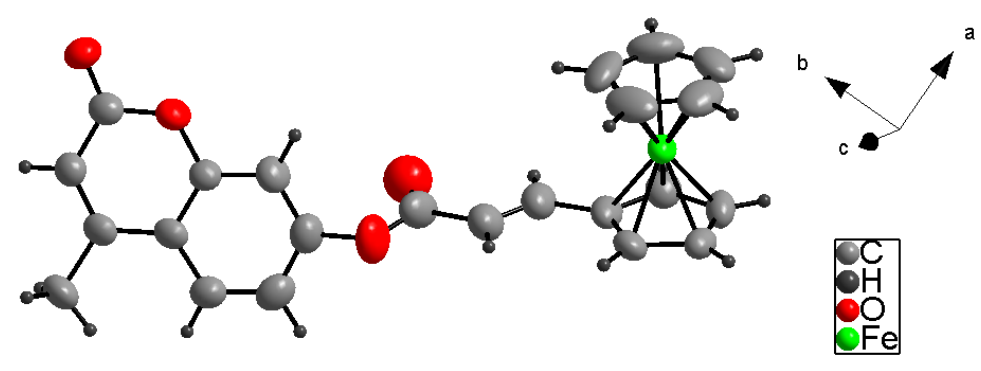

7d (CCDC: 727726) 


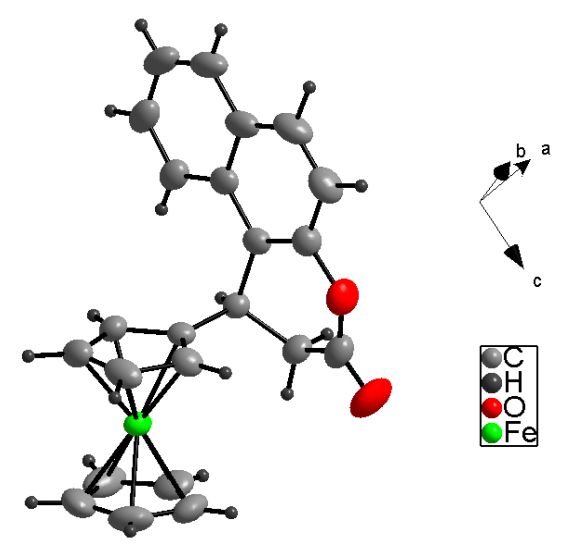

6a (CCDC: 727724)

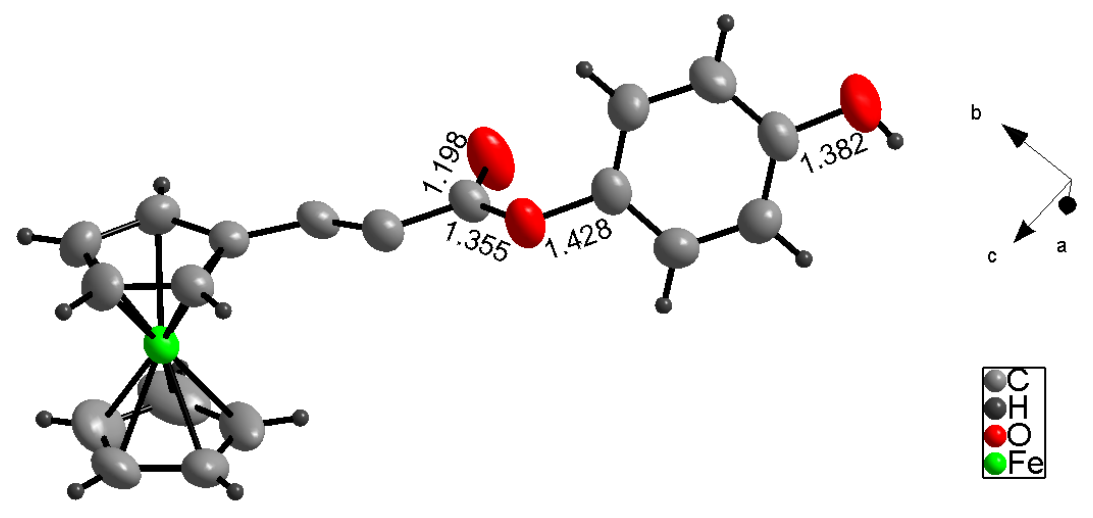

7e (CCDC: 727725)

Figure 1. The molecular structures of some products.

In the three esterified products, the two Cp rings in ferrocenyl are overlapped and parallel. The ferrocenyl, $\mathrm{C}=\mathrm{C}$ double bond and carbonyl are co-planar, but the phenyl is not co-planar with them because the $\mathrm{H}$ atoms of phenyl will be repulsed by the $\mathrm{O}$ atom of the carbonyl, and the angles between the plane of phenyl and that of carbonyl are all about $80^{\circ} \mathrm{C}$. We also find that all $\mathrm{C}=\mathrm{C}$ double bonds have a tran-configuration, which agrees with coupling constants in the double bond $(15.6 \mathrm{~Hz}$, the coupling constants of $\mathrm{H}$ atom in cis-double bond is $7 \sim 11 \mathrm{~Hz})$. In the esterified products, for example 7e (see Figure 1-7e), the $\mathrm{O}$ atom connects both with the carbonyl and benzene ring, in which the bond lengths of the two C-O bonds are $0.1355 \mathrm{~nm}$ and $0.1428 \mathrm{~nm}$, respectively. This means the $\mathrm{O}$ atom does not conjugate with the benzene ring but conjugates with the carbonyl, $\mathrm{C}=\mathrm{C}$ double bond and ferrocenyl. In addition, the carbonyl is an electronwithdrawing group, so the substituted $\mathrm{Cp}$ ring will be electron-deficient compared with the unsubstituted $\mathrm{Cp}$ ring, and the chemical shifts of the four $\mathrm{H}$ atoms of the substituted $\mathrm{Cp}$ ring occur at 4.46( $\mathrm{m}$-site) and $4.54 \mathrm{ppm}(\mathrm{o}$-site), while that of the five $\mathrm{H}$ atoms of the unsubstituted $\mathrm{Cp}$ ring occur in $4.20 \mathrm{ppm}$. In the case of ring closure product $6 \mathbf{6}$, we can find that the carbonyl does not conjugate with any $\mathrm{Cp}$ ring. The chemical environments of the nine $\mathrm{H}$ atoms of 
ferrocenyl are almost equal, which means that the peaks of the nine $\mathrm{H}$ atoms in the ${ }^{1} \mathrm{H}$ NMR overlap. Finally, our experimental result shows that ring closure products $6 \mathbf{a}$ and $\mathbf{6 b}$ both are yellow powders, while the five esterified products $\mathbf{7 a} \mathbf{7 e}$ are all red powders.

\section{F-C alkylation of ferrocenyl acrylic amide to ferrocenyl 3,4-dihydroquinolone}

Eleven ferrocenyl acrylic anilides have been prepared, and most of them can react smoothly in TFA to provide dihydroquinolones $\mathbf{1 0}$ in good yields after only an hour at $30{ }^{\circ} \mathrm{C}$, the results of which are listed in Table 3.

Table 3. The hydroarylation of ferroceneyl acrylic anilides Ar-NH-COCH=CH-Fc

(min) $\begin{gathered}\text { Yield (\%) } \\ \text { Time } \\ (\mathrm{min})\end{gathered}$


<smiles>[3H]C1CC(=O)Nc2c1ccc(Cl)c2Cl</smiles>

$10 f$<smiles>COc1ccc(OC)c2c1NC(=O)CC2F</smiles>

$10 \mathrm{~g}$<smiles>COc1cc2c(cc1OC)C(F)CC(=O)N2</smiles>

10h<smiles>Cc1ccc(C)c2c1NC(=O)CC2F</smiles>

$10 \mathrm{i}$<smiles>O=C1CC([18F])c2ccc3ccccc3c2N1</smiles>

10j<smiles>O=[N+]([O-])c1ccc(Cl)c(Cl)c1</smiles>

60 25

$9 \mathbf{f}$<smiles>COc1ccc(OC)c(OC)c1</smiles>

10 95<smiles>COc1ccc(C)cc1OC</smiles>

15 96 9h<smiles>Cc1ccc(C)c(C)c1</smiles>

9k 9j

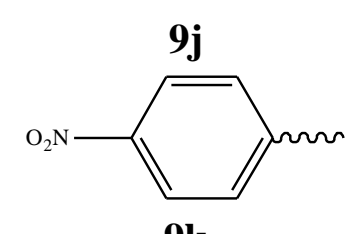

9i<smiles>Sc1cccc2ccccc12</smiles>

10 97

No 3,4-dihydroquinolone product

The hydroarylation of ferrocenyl acrylic anilides $\mathbf{9}$ is easier than that of ferrocenyl acrylic esters 7, and all ferrocenyl acrylic anilides, except of 9k, can obtain ferrocenyl 3,4dihydroquinolones in the presence of TFA. The reason is that the amide group ($\mathrm{NHCOCH}=\mathrm{CHFc}$ ) is a better electron-donating group than the ester group $(-\mathrm{OCOCH}=\mathrm{CHFc})$. Electronic factors play an important role in hydroarylation and very strong electron-withdrawing groups make hydroarylation impossible $(\mathbf{9 k})$. The chlorine atom is a strong electron-withdrawing group for its meta-position, so the hydroarylation of $9 \mathrm{c}$ to $\mathbf{1 0 c}$ is difficult. On the other hand, chorine is a weak electron-withdrawing groups for its para-position due to its conjugative effect, 
so $9 \mathrm{e}$ can hydroarylate to $\mathbf{1 0 e - 1}$ and $\mathbf{1 0 e - 2}$ easily (the identification of regional isomers, such as 10e-1 and 10e-2, is based on chemical shifts and coupling constants of $\mathrm{H}$ atoms in ${ }^{1} \mathrm{H} \mathrm{NMR}$ ). Since ferrocenyl 3,4-dihydroquinolones all have an N-H bond which can form an intermolecular hydrogen bond, their melting points are higher than those of ferrocenyl dihydrocoumarin. Finally, we find that all ferrocenyl acrylic amides 9 are red solids and all ferrocenyl 3,4dihydroquinolones $\mathbf{1 0}$ are yellow solids, which suggests that the structures of $\mathbf{9}$ and $\mathbf{1 0}$ are similar to those of $\mathbf{7}$ and $\mathbf{6}$, respectively.

\section{Why cannot strong acid catalyze hydroarylation of acrylic anilides to dihydroquinolones?}

Our experiment proves that TFA $\left(\mathrm{CF}_{3} \mathrm{COOH}\right.$, pka= 0.3$)$ is a good catalyst for the hydroarylation of acrylic anilides to dihydroquinolones, but $\mathrm{c}-\mathrm{H}_{2} \mathrm{SO}_{4}(\mathrm{pKa}<-7)$ can not catalyze this reaction. The hydroarylation of acrylic anilide to dihydroquinolone is an electrophilic substitution reaction and its mechanism has been proposed by Tunge ${ }^{19}$ as shown in scheme 2 .

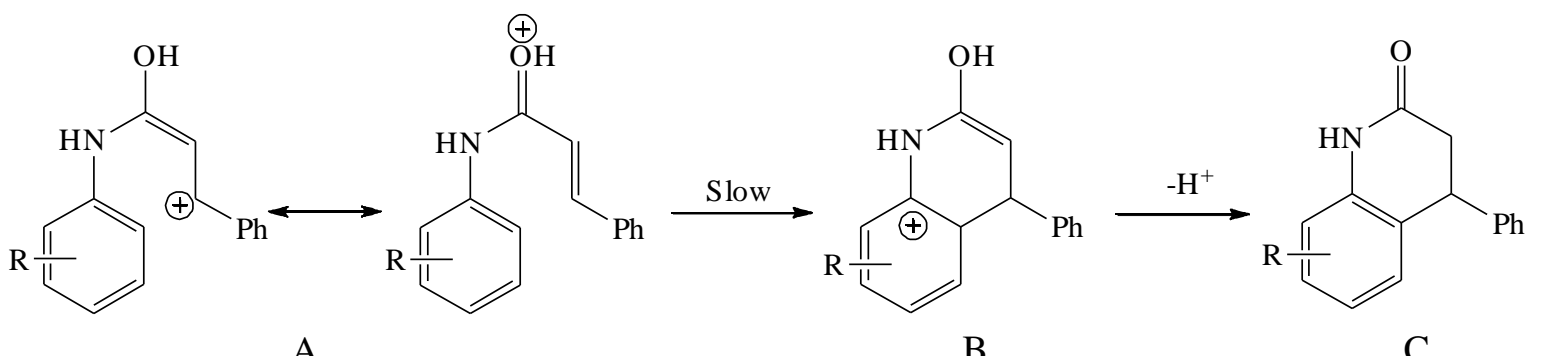

Scheme 2. The mechanism for hydroarylation proposed by Tunge.

The transition state of $\mathrm{A}$ to $\mathrm{B}$ has been calculated in this paper $\left(\mathrm{R}=-\mathrm{OCH}_{3}\right)$ and the structures of reactant A and this transition state are shown in Figure 2.
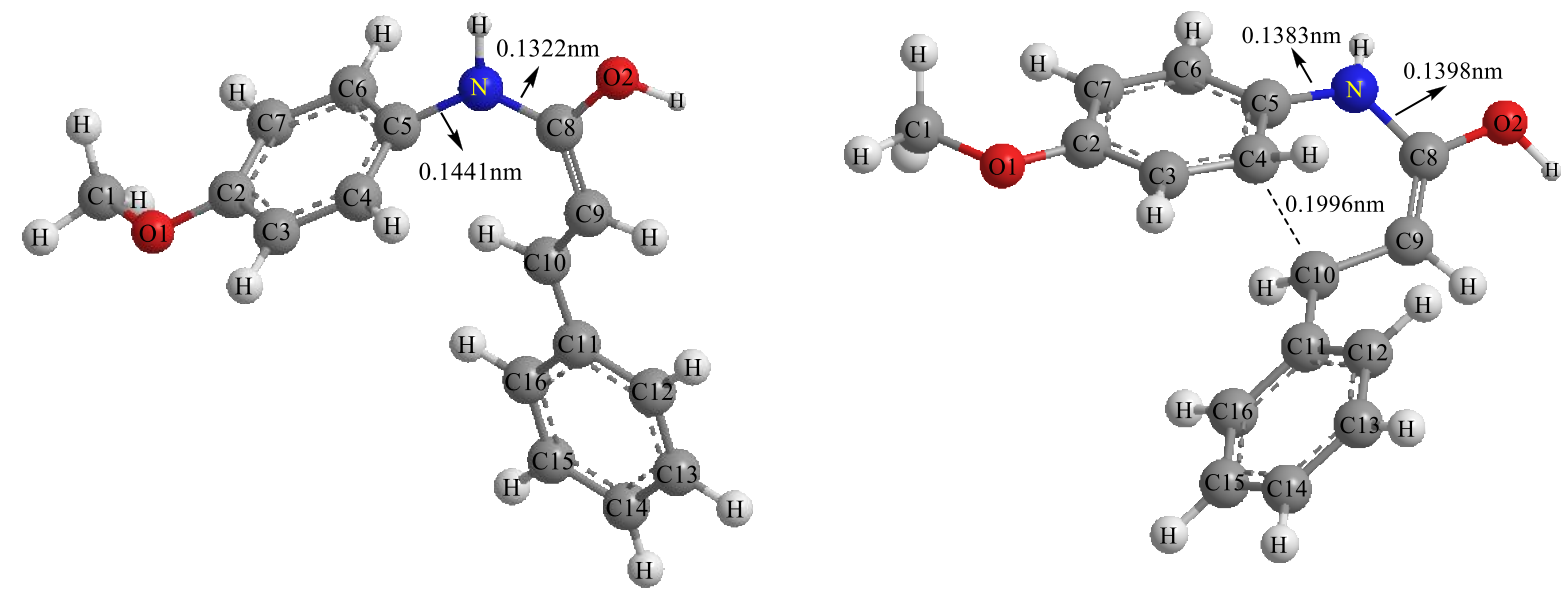

Figure 2. The optimized structures of reactant A and transition state of the reaction of A to B. 
If the bond lengths of $\mathrm{C} 5-\mathrm{N}$ and $\mathrm{N}-\mathrm{C} 8$ are compared in reactant $\mathbf{A}$ and the transition state, the following is noted: (1) in reactant $\mathbf{A}$, the $\mathrm{N}$ atom conjugates with the enol mainly because the positive charge is on $\mathrm{C} 10$ atom, so $\mathrm{N}-\mathrm{C} 8$ bond is a partial double bond and its bond length is $0.1322 \mathrm{~nm}$; (2) in the transition state, the $\mathrm{N}$ atom conjugates with the benzene ring mainly because positive charge is on the benzene ring, so $\mathrm{C} 5-\mathrm{N}$ bond is a partial double bond and its bond length is $0.1383 \mathrm{~nm}$. This result indicates that the lone pair of electron on the $\mathrm{N}$ atom is very important and it can stabilize the positive charge, no matter if the positive charge is on $\mathrm{C} 10$ atom or on benzene ring $(\mathrm{C} 2 \sim \mathrm{C} 7)$. The acidity of $\mathrm{c}-\mathrm{H}_{2} \mathrm{SO}_{4}$ is strong enough to protonate the $\mathrm{N}$ atom of acrylic anilide and a protonated $\mathrm{N}$ atom can not stabilize the positive charge caused by electrophilic attack. Therefore, $\mathrm{c}-\mathrm{H}_{2} \mathrm{SO}_{4}$ can not catalyze hydroarylation of acrylic anilides to dihydroquinolones.

\section{Conclusions}

Since the ferrocenyl has large spatial obstacle, the ring closure of phenol and ferrocenyl acrylic acid to ferrocenyl dihydrocoumarin is difficult. Only phenols those have large electronic density in ortho-site of the hydroxyl, such as resorcinol and 2-naphthalenol, that can get ring closure product. But the ring closure of ferrocenyl acrylic anilides to ferrocenyl 3,4-dihydroquinolones is easy unless there is a strong electron-withdrawing group in the phenyl ring, the weak electronwithdrawing groups only make the reaction slow but do not hold back it.

\section{Experimental Section}

\section{Computational details}

All geometry optimizations of reactants and products are performed by means of B3LYP method with Gaussian 03 program and 6-311G(d) basis set for all atoms. The transition states are all obtained from QST3 calculations and are affirmed by calculations of vibration frequency. All calculated details are available from authors.

General. All reagents were commercially available and used as received without further purification. All solvents were distilled and dried before use. Melting points were measured with WRS-1B micromelting apparatus. ${ }^{1} \mathrm{H}$ NMR spectra were recorded on a Bruker spectrometer at $400 \mathrm{MHz}$, using TMS as internal standard. The chemical shift values are on $\delta$ scale and the coupling constants $(J)$ are in Hz. Elemental analyses were conducted by the Service Center of Elemental Analysis of Fujian Institute of Research on the Structure of Matter, Chinese Academy of Sciences. The IR spectra were recorded on Perkin- Elmer 2000 FT-IR spectrometer. 


\section{Procedure for the synthesis of esterified product (7) and ring closure product (6)}

The compound $\mathbf{4}$ and $\mathbf{5}$ are synthesized according to reference[21]. 0.38g Phenol (4.0mmol), $1.03 \mathrm{~g}$ ferrocenyl acrylic acid $\mathbf{5}(4.0 \mathrm{mmol})$ and $150 \mathrm{~mL}$ benzene were added into a $250 \mathrm{~mL}$ round bottom flask, $0.5 \mathrm{~mL}$ concentrated sulfuric acid was added dropwise under nitrogen, then a water separator was put on the flask. The reaction mixture was stirred at $90{ }^{\circ} \mathrm{C}$ in oil bath for about $10 \mathrm{~h}$ till the detected spot of ferrocenyl acrylic acid on TLC becomes very weak. The reaction mixture was then washed with saturated $\mathrm{NaCl}$ solution $(30 \mathrm{~mL} \times 2)$, dried over anhydrous $\mathrm{MgSO}_{4}$, and concentrated under reduced pressure. The residue was purified by column chromatography on silica gel using a mixture of petroleum ether $\left(60 \sim 90{ }^{\circ} \mathrm{C}\right)$ and ethyl acetate $(8: 1, \mathrm{v} / \mathrm{v})$ as an eluent to give phenyl ferrocenyl cinnamate $7 \mathbf{a}$ in $40 \%$.

1,2-Dihydro-1-ferrocenyl-3H-naphtho-[2,1b]pyran-3-one (6a). Yellow solid, mp 166.1-167.5 ${ }^{\circ} \mathrm{C}$. ${ }^{1} \mathrm{HNMR}\left(400 \mathrm{MHz}, \mathrm{CDCl}_{3}\right): \delta 3.08\left(1 \mathrm{H}, \mathrm{dd}, J=6.4 \mathrm{~Hz}\right.$ and $\left.16.0 \mathrm{~Hz}, \mathrm{C}-3 \mathrm{H}_{\mathrm{a}}\right), 3.41(1 \mathrm{H}, \mathrm{d}, J$ $\left.=6.4 \mathrm{~Hz}, \mathrm{C}-3 \mathrm{H}_{\mathrm{\beta}}\right), 4.09-4.23(\mathrm{~m}, 9 \mathrm{H}, \mathrm{Cp}-\mathrm{H}), 4.69(1 \mathrm{H}, \mathrm{d}, J=6.0 \mathrm{~Hz}, \mathrm{C}-4 \mathrm{H}), 7.30-8.11(\mathrm{~m}, 6 \mathrm{H}$, $\mathrm{ArH})$; IR (KBr): 3096 (Ar-CH), $1715(\mathrm{C}=\mathrm{O}), 1626$, $1452(\mathrm{C}=\mathrm{C}), 1288,1160$ (Cp C=C), 492, 482 ( Fe-Cp); Anal. Calcd. for $\mathrm{C}_{23} \mathrm{H}_{18} \mathrm{FeO}_{2}$ : C, 72.27; H, 4.75. Found: C, 71.95; H, 4.70.

7-Hydroxy-4-ferrocenyl-3,4-dihydrocoumarin (6b). Yellow solid, mp 147.8-149.1 ${ }^{\circ} \mathrm{C}$. ${ }^{1} \mathrm{HNMR}\left(400 \mathrm{MHz}, \mathrm{CDCl}_{3}\right): \delta 2.98\left(1 \mathrm{H}, \mathrm{dd}, J=6.0 \mathrm{~Hz}\right.$ and $\left.16.0 \mathrm{~Hz}, \mathrm{C}-3 \mathrm{H}_{\mathrm{a}}\right), 3.10(1 \mathrm{H}, \mathrm{dd}, J=$ $5.6 \mathrm{~Hz}$ and $\left.16.0 \mathrm{~Hz}, \mathrm{C}-3 \mathrm{H}_{\beta}\right), 3.95(1 \mathrm{H}, \mathrm{t}, J=6.0 \mathrm{~Hz}, \mathrm{C} 4-\mathrm{H}), 4.02-4.19(9 \mathrm{H}, \mathrm{m}, \mathrm{Cp}-\mathrm{H}), 5.80(1 \mathrm{H}$, br s, OH), 6.59-6.64 (2H, m, o-Ar-H of OH), 6.98 (1H, d, $J=8.0 \mathrm{~Hz}, m-\mathrm{Ar}-\mathrm{H}$ of OH); IR(KBr): 3092 (Ar-CH), 2925 (Saturated C-H), $1734(\mathrm{C}=\mathrm{O}), 1623,1509(\mathrm{C}=\mathrm{C}), 1278,1153$ (Cp C=C), 492,481,469 (Fe-Cp); Anal. Calcd. for $\mathrm{C}_{19} \mathrm{H}_{16} \mathrm{FeO}_{3} \cdot 0.5 \mathrm{H}_{2} \mathrm{O}$ : C, 63.89; H, 4.80. Found: C, 63.63; H, 4.77.

Phenyl ferrocenyl acrylate (7a). Red solid, mp 192.3-193.5 ${ }^{\circ} \mathrm{C} .{ }^{1} \mathrm{HNMR}\left(400 \mathrm{MHz}, \mathrm{CDCl}_{3}\right): \delta$ 4.19 (5H, s, Cp-H), 4.49 (2H, t, $J=1.6 \mathrm{~Hz}, \mathrm{Cp}-\mathrm{H}), 4.58$ (2H, t, $J=1.6 \mathrm{~Hz}, \mathrm{Cp}-\mathrm{H}), 6.22$ (1H, d, $J$ $=15.6$, = CH-C = O), $7.77(1 \mathrm{H}, \mathrm{d}, J=16.0, \mathrm{Cp}-\mathrm{CH}=)$, 7.18-7.45 (5H, m, $\left.\mathrm{C}_{6} \mathrm{H}_{5}\right) ; \mathrm{IR}(\mathrm{KBr}): 3088$ (Ar-CH), $1720(\mathrm{C}=\mathrm{O}), 1622,1450(\mathrm{C}=\mathrm{C}), 1260,1142(\mathrm{Cp} \mathrm{C}=\mathrm{C})$, 502, 492 (Fe-Cp); Anal. Calcd. for $\mathrm{C}_{19} \mathrm{H}_{16} \mathrm{FeO}_{2}$ : C, 68.70; H, 4.85. Found: C, 68.75; H, 4.93.

4-Methylphenyl ferrocenyl acrylate (7b) Red solid, mp 134.0-135.2 ${ }^{\circ} \mathrm{C} .{ }^{1} \mathrm{HNMR}(400 \mathrm{MHz}$, $\left.\mathrm{CDCl}_{3}\right): \delta 4.21(5 \mathrm{H}, \mathrm{s}, \mathrm{Cp}-\mathrm{H}), 4.48(2 \mathrm{H}, \mathrm{t}, J=1.6 \mathrm{~Hz}, \mathrm{Cp}-\mathrm{H}), 4.57(2 \mathrm{H}, \mathrm{t}, J=1.6 \mathrm{~Hz}, \mathrm{Cp}-\mathrm{H})$, $6.21\left(1 \mathrm{H}, \mathrm{d}, J=15.6\right.$, = CH-C = O), $7.76(1 \mathrm{H}, \mathrm{d}, J=16.0, \mathrm{Cp}-\mathrm{CH}=), 7.05-7.23\left(5 \mathrm{H}, \mathrm{m}, \mathrm{C}_{6} \mathrm{H}_{5}\right)$; IR(KBr): 3084 (Ar-CH), $1717(\mathrm{C}=\mathrm{O})$, 1624, $1508(\mathrm{C}=\mathrm{C})$, 1247, $1138(\mathrm{Cp} \mathrm{C}=\mathrm{C}), 499,482$ (Fe-Cp); Anal. Calcd. for $\mathrm{C}_{20} \mathrm{H}_{18} \mathrm{FeO}_{2}$ : C, 69.39; H, 5.24. Found: C, 69.40; H, 5.35.

4-Methoxyphenyl ferrocenyl acrylate (7c). Red solid, mp 104.5-105.6 ${ }^{\circ} \mathrm{C}$. ${ }^{1} \mathrm{HNMR}(400 \mathrm{MHz}$, $\left.\mathrm{CDCl}_{3}\right): \delta 3.84\left(3 \mathrm{H}, \mathrm{s}, \mathrm{CH}_{3}\right), 4.21(5 \mathrm{H}, \mathrm{s}, \mathrm{Cp}-\mathrm{H}), 4.48(2 \mathrm{H}, \mathrm{t}, J=1.6 \mathrm{~Hz}, \mathrm{Cp}-\mathrm{H}), 4.57(2 \mathrm{H}, \mathrm{t}, J=$ $1.6 \mathrm{~Hz}, \mathrm{Cp}-\mathrm{H}), 6.21(1 \mathrm{H}, \mathrm{d}, J=15.6$, = CH-C = O), $7.76(1 \mathrm{H}, \mathrm{d}, J=16.0, \mathrm{Cp}-\mathrm{CH}=), 6.93(2 \mathrm{H}$, m, Ar-H), 7.09 (2H, m, Ar-H); IR(KBr): 3089 (Ar-CH), $2924\left(v_{C H}\right), 1719$ (C= O), 1626, 1506 $(\mathrm{C}=\mathrm{C}), 1248,1138$ (Cp C = C), 496, 481 (Fe-Cp);

4-Methyl-2-oxo-2H-chromen-7yl-ferrocenyl acrylate (7d). Red solid, mp 175.8-176.9 ${ }^{\circ} \mathrm{C}$. ${ }^{1} \mathrm{HNMR}\left(400 \mathrm{MHz}, \mathrm{CDCl}_{3}\right): \delta 2.48\left(3 \mathrm{H}, \mathrm{s}, \mathrm{CH}_{3}\right), 4.24(5 \mathrm{H}, \mathrm{s}, \mathrm{Cp}-\mathrm{H}), 4.52(2 \mathrm{H}, \mathrm{t}, J=1.6 \mathrm{~Hz}, \mathrm{Cp}-$ $\mathrm{H}), 4.59(2 \mathrm{H}, \mathrm{t}, J=1.6 \mathrm{~Hz}, \mathrm{Cp}-\mathrm{H}), 6.21(1 \mathrm{H}, \mathrm{d}, J=15.6,=\mathrm{CH}-\mathrm{C}=\mathrm{O}), 6.30(1 \mathrm{H}, \mathrm{s}, \mathrm{CH}=$ of 
coumarin), 7.18-7.23 (2H, m, C6-H and C8-H), $7.54(1 \mathrm{H}, \mathrm{d}, J=8.0 \mathrm{~Hz}, \mathrm{C} 5-\mathrm{H}), 7.81(1 \mathrm{H}, \mathrm{d}, J=$ 15.6, Cp-CH = ); IR(KBr): 3087 (Ar-CH), $1732(\mathrm{C}=\mathrm{O}), 1630,1612,1497(\mathrm{C}=\mathrm{C}), 1233,1146$, $(\mathrm{Cp} \mathrm{C}=\mathrm{C}), 482$ (Fe-Cp); Anal. Calcd. for $\mathrm{C}_{23} \mathrm{H}_{18} \mathrm{FeO}_{4} \cdot 0.5 \mathrm{H}_{2} \mathrm{O}: \mathrm{C}, 65.27$; H, 4.52. Found: $\mathrm{C}$, $65.44 ; \mathrm{H}, 4.46$.

4-Hydroxyphenyl ferrocenyl acrylate (7e). Red solid, mp 178.7-179.8 ${ }^{\circ} \mathrm{C} .{ }^{1} \mathrm{HNMR}(400 \mathrm{MHz}$, $\left.\mathrm{CDCl}_{3}\right): \delta 4.20(5 \mathrm{H}, \mathrm{s}, \mathrm{Cp}-\mathrm{H}), 4.46(2 \mathrm{H}, \mathrm{t}, J=1.6 \mathrm{~Hz}, \mathrm{Cp}-\mathrm{H}), 4.54(2 \mathrm{H}, \mathrm{t}, J=1.6 \mathrm{~Hz}, \mathrm{Cp}-\mathrm{H})$, $6.17(1 \mathrm{H}, \mathrm{d}, J=15.6$, = CH-C = O), $6.79(2 \mathrm{H}, \mathrm{d}, J=8.4 \mathrm{~Hz}, \mathrm{Ar}-\mathrm{H}), 7.00(2 \mathrm{H}, \mathrm{d}, J=8.8 \mathrm{~Hz}, \mathrm{Ar}-$ $\mathrm{H}), 7.73(1 \mathrm{H}, \mathrm{d}, J=15.6, \mathrm{Cp}-\mathrm{CH}=$ ); IR(KBr): $3312(\mathrm{OH}), 3087(\mathrm{Ar}-\mathrm{CH}), 1683(\mathrm{C}=\mathrm{O}), 1620$, $1508(\mathrm{C}=\mathrm{C}), 1190,1150(\mathrm{Cp} \mathrm{C}=\mathrm{C}), 499,481$ (Fe-Cp); Anal. Calcd. for $\mathrm{C}_{19} \mathrm{H}_{16} \mathrm{FeO}_{3}: \mathrm{C}, 65.54$; H, 4.63. Found: C, 65.85; H, 5.11.

\section{Procedure for the synthesis of ferrocenyl acrylic amide 6 and ferrocenyl dihydroquionlin-2- one (10)}

Intermediate 8 was synthesized according to the document [22]. 8 (1.0 mmol) and aniline (1.0 mmol) were added into a $50 \mathrm{~mL}$ round bottom flask under nitrogen, then $15 \mathrm{ml}$ dried 1,2 dichloroethane and triethylamine $(1.0 \mathrm{mmol})$ were subsequently added. The reaction mixture was stirred at $30{ }^{\circ} \mathrm{C}$ in water bath till the detected spot of ferrocenyl acryloyl chloride on TLC becomes very weak. The reaction mixture was then washed with diluted hydrochloric acid, diluted $\mathrm{NaOH}$ solution and water in turn, dried over anhydrous $\mathrm{MgSO}_{4}$, and concentrated under reduced pressure. The residue was purified by column chromatography on silica gel using dichloromethane as an eluent to give the intermediate 9a in $95 \%$.

9a $(0.5 \mathrm{mmol})$ was added into a $50 \mathrm{~mL}$ round bottom flask under nitrogen, the $15 \mathrm{ml}$ dried $1,2-$ dichloroethane and $2 \mathrm{ml}$ TFA were added. The reaction mixture was stirred at $30^{\circ} \mathrm{C}$ in water bath till the detected spot of the intermediate amide on TLC disappeared. The reaction mixture was washed with $\mathrm{NaOH}$ solution $(0.5 \mathrm{~mol} / \mathrm{L})$ and water, dried over anhydrous $\mathrm{MgSO}_{4}$, and concentrated under reduced pressure. The residue was purified by column chromatography on silica gel using a mixture of petroleum ether $\left(60 \sim 90{ }^{\circ} \mathrm{C}\right)$ and ethyl acetate $(4: 1, \mathrm{v} / \mathrm{v})$ as an eluent to give $10 \mathrm{a}$ in $88 \%$.

4-Ferrocenyl-3,4-dihydroquionlin-2-one (10a). Yellow solid, mp 198.6-200.1 ${ }^{\circ} \mathrm{C}$. ${ }^{1} \mathrm{HNMR}$ $\left(400 \mathrm{MHz}, \mathrm{CDCl}_{3}\right): \delta 2.89\left(1 \mathrm{H}, \mathrm{dd}, J=7.2 \mathrm{~Hz}\right.$ and $\left.16.0 \mathrm{~Hz}, \mathrm{C}-3 \mathrm{H}_{a}\right), 3.05(1 \mathrm{H}, \mathrm{dd}, J=6.0 \mathrm{~Hz}$ and $\left.16.0 \mathrm{~Hz}, \mathrm{C}-3 \mathrm{H}_{\beta}\right), 4.00(1 \mathrm{H}, \mathrm{t}, J=6.4 \mathrm{~Hz}, \mathrm{C} 4-\mathrm{H}), 4.08-4.18(9 \mathrm{H}, \mathrm{m}, \mathrm{Cp}-\mathrm{H}), 6.71(1 \mathrm{H}, \mathrm{d}, J=$ $7.2 \mathrm{~Hz}, \mathrm{C} 8-\mathrm{H}), 6.97(1 \mathrm{H}, \mathrm{t}, J=7.6 \mathrm{~Hz}, \mathrm{C} 6-\mathrm{H}), 7.08(1 \mathrm{H}, \mathrm{d}, J=7.2 \mathrm{~Hz}, \mathrm{C} 5-\mathrm{H}), 7.16(1 \mathrm{H}, \mathrm{t}, J=7.6$ Hz, C7-H), $7.72(1 \mathrm{H}, \mathrm{s}, \mathrm{N}-\mathrm{H})$; IR(KBr): $3217(\mathrm{NH}), 3073(\mathrm{Ar}-\mathrm{CH}), 2986$ and $2908\left(\mathrm{CH}_{2}\right.$ and $\mathrm{CH}-\mathrm{Fc}), 1676(\mathrm{C}=\mathrm{O})$, 1598, $1504(\mathrm{C}=\mathrm{C}), 1383,1248(\mathrm{C}-\mathrm{N}), 1168,1106(\mathrm{Cp} \mathrm{C}=\mathrm{C}), 500,483$ (Fe-Cp); Anal. Calcd. for $\mathrm{C}_{19} \mathrm{H}_{17} \mathrm{FeNO} \cdot 0.3 \mathrm{H}_{2} \mathrm{O}$ : C, 67.80; H, 5.27; N, 4.16 . Found: C, 67.68; $\mathrm{H}, 4.99 ; \mathrm{N}, 3.99$.

4-Ferrocenyl-8-methoxyl-3,4-dihydroquionlin-2-one (10b). Yellow solid, mp 174.2-175.3 ${ }^{\circ} \mathrm{C}$. ${ }^{1} \mathrm{HNMR}\left(400 \mathrm{MHz}, \mathrm{CDCl}_{3}\right): \delta 2.85\left(1 \mathrm{H}, \mathrm{dd}, J=4.8 \mathrm{~Hz}\right.$ and $\left.16.0 \mathrm{~Hz}, \mathrm{C}-3 \mathrm{H}_{a}\right), 3.05(1 \mathrm{H}, \mathrm{dd}, J=$ $4.8 \mathrm{~Hz}$ and $\left.16.4 \mathrm{~Hz}, \mathrm{C}-3 \mathrm{H}_{\beta}\right), 3.84\left(3 \mathrm{H}, \mathrm{s}, \mathrm{OCH}_{3}\right), 3.96(1 \mathrm{H}, \mathrm{t}, J=6.0 \mathrm{~Hz}, \mathrm{C} 4-\mathrm{H}), 4.18-4.24(9 \mathrm{H}$, m, Cp-H), 6.68(1H, d, $J=7.6 \mathrm{~Hz}, \mathrm{C} 5-\mathrm{H}), 6.73(1 \mathrm{H}, \mathrm{d}, J=8.0 \mathrm{~Hz}, \mathrm{C} 7-\mathrm{H}), 6.91(1 \mathrm{H}, \mathrm{t}, J=7.6 \mathrm{~Hz}$, 
C6-H), 7.80 (1H, s, N-H); IR(KBr): $3193(\mathrm{NH}), 3089$ (Ar-CH), 2939, 2904, $2851\left(\mathrm{OCH}_{3}, \mathrm{CH}_{2}\right.$ and $\mathrm{CH}-\mathrm{Fc}), 1679(\mathrm{C}=\mathrm{O}), 1594,1498(\mathrm{C}=\mathrm{C}), 1266,1244(\mathrm{C}-\mathrm{N}), 1164,1096(\mathrm{Cp} \mathrm{C}=\mathrm{C}), 494$, 484 (Fe-Cp); Anal. Calcd. for $\mathrm{C}_{20} \mathrm{H}_{19} \mathrm{FeNO}_{2}$ : C, 66.50; H, 5.30; N, 3.88. Found: C, 66.10; H, $5.31 ; \mathrm{N}, 3.70$.

4-Ferrocenyl-6-chloro-3,4-dihydroquionlin-2-one (10c). Yellow solid, mp 186.6-187.2 ${ }^{\circ} \mathrm{C}$. ${ }^{1} \mathrm{HNMR}\left(400 \mathrm{MHz}, \mathrm{CDCl}_{3}\right): \delta 2.87\left(1 \mathrm{H}, \mathrm{dd}, J=6.8 \mathrm{~Hz}\right.$ and $\left.16.0 \mathrm{~Hz}, \mathrm{C}-3 \mathrm{H}_{\mathrm{a}}\right), 3.03(1 \mathrm{H}, \mathrm{dd}, J=$ $6.0 \mathrm{~Hz}$ and $\left.16.0 \mathrm{~Hz}, \mathrm{C}-3 \mathrm{H}_{\beta}\right), 3.98(1 \mathrm{H}, \mathrm{t}, J=6.4 \mathrm{~Hz}, \mathrm{C} 4-\mathrm{H}), 4.10-4.20(9 \mathrm{H}, \mathrm{m}, \mathrm{Cp}-\mathrm{H}), 6.64(1 \mathrm{H}$, $\mathrm{d}, J=8.4 \mathrm{~Hz}, \mathrm{C} 8-\mathrm{H}), 7.06(1 \mathrm{H}, \mathrm{d}, J=1.6 \mathrm{~Hz}, \mathrm{C} 5-\mathrm{H}), 7.11(1 \mathrm{H}, \mathrm{dd}, J=2.4 \mathrm{~Hz}$ and $8.4 \mathrm{~Hz}, \mathrm{C} 7-$ H), 7.52 (1H, s, N-H); IR(KBr): 3199 (NH), 3089 (Ar-CH), 3055 (Ar-CH), $2949\left(\mathrm{CH}_{2}\right), 1675$ (C = O), 1604, $1487(\mathrm{C}=\mathrm{C})$, 1372, 1278(C-N), 1176, 1104 (Cp C = C), 484, 461 (Fe-Cp); Anal. Calcd. for $\mathrm{C}_{19} \mathrm{H}_{16} \mathrm{ClFeNO} \cdot 1.8 \mathrm{H}_{2} \mathrm{O}$ : C, 57.33; H, 4.96; N, 3.52. Found: C, 57.51; H, 4.78; N, 3.39 .

4-Ferrocenyl-7-methoxyl-3,4-dihydroquionlin-2-one (10d-1). Yellow solid, mp 212.7-214.2 ${ }^{\circ} \mathrm{C} .{ }^{1} \mathrm{HNMR}\left(400 \mathrm{MHz}, \mathrm{CDCl}_{3}\right): \delta 2.85\left(1 \mathrm{H}, \mathrm{dd}, J=6.4 \mathrm{~Hz}\right.$ and $\left.16.0 \mathrm{~Hz}, \mathrm{C}-3 \mathrm{H}_{a}\right), 3.01(1 \mathrm{H}, \mathrm{dd}, J$ $=6.0 \mathrm{~Hz}$ and $\left.16.0 \mathrm{~Hz}, \mathrm{C}-3 \mathrm{H}_{\beta}\right), 3.76\left(3 \mathrm{H}, \mathrm{s}, \mathrm{OCH}_{3}\right), 3.94(1 \mathrm{H}, \mathrm{t}, J=6.0 \mathrm{~Hz}, \mathrm{C} 4-\mathrm{H}), 4.08-4.19$ $(9 \mathrm{H}, \mathrm{m}, \mathrm{Cp}-\mathrm{H}), 6.26(1 \mathrm{H}, \mathrm{d}, J=2.0 \mathrm{~Hz}, \mathrm{C} 8-\mathrm{H}), 6.50(1 \mathrm{H}, \mathrm{dd}, J=2.4 \mathrm{~Hz}$ and $8.4 \mathrm{~Hz}, \mathrm{C} 6-\mathrm{H}), 6.97$ $(1 \mathrm{H}, \mathrm{t}, J=8.4 \mathrm{~Hz}, \mathrm{C} 5-\mathrm{H}), 7.59$ (1H, s, N-H); IR (KBr): $3195(\mathrm{NH}), 3096(\mathrm{Ar}-\mathrm{CH}), 2996,2936$, 2969, $2928\left(\mathrm{OCH}_{3}, \mathrm{CH}_{2}\right.$ and $\left.\mathrm{CH}-\mathrm{Fc}\right), 1683(\mathrm{C}=\mathrm{O}), 1592,1491(\mathrm{C}=\mathrm{C}), 1372,1284(\mathrm{C}-\mathrm{N})$, 1166, 1128 (Cp C = C), 487, 449 (Fe-Cp); Anal. Calcd. for $\mathrm{C}_{20} \mathrm{H}_{19} \mathrm{FeNO}_{2} \cdot 0.4 \mathrm{H}_{2} \mathrm{O}: \mathrm{C}, 65.20 ; \mathrm{H}$, 5.42; N, 3.80. Found: C, 65.15; H, 5.02; N, 3.78.

4-Ferrocenyl-5-methoxyl-3,4-dihydroquionlin-2-one (10d-2). Yellow solid, mp 236.5-237.7 ${ }^{\circ} \mathrm{C} .{ }^{1} \mathrm{HNMR}\left(400 \mathrm{MHz}, \mathrm{CDCl}_{3}\right): \delta 2.85\left(1 \mathrm{H}, \mathrm{dd}, J=6.8 \mathrm{~Hz}\right.$ and $\left.16.0 \mathrm{~Hz}, \mathrm{C}-3 \mathrm{H}_{\mathrm{a}}\right), 3.06(1 \mathrm{H}, \mathrm{d}, J$ $\left.=15.6 \mathrm{~Hz}, \mathrm{C}-3 \mathrm{H}_{\beta}\right), 3.94\left(3 \mathrm{H}, \mathrm{s}, \mathrm{OCH}_{3}\right), 4.09-4.34(9 \mathrm{H}, \mathrm{m}, \mathrm{Cp}-\mathrm{H}), 4.40(1 \mathrm{H}, \mathrm{d}, J=6.4 \mathrm{~Hz}, \mathrm{C} 4-\mathrm{H}$ ), 6.33(1H, d, $J=7.6 \mathrm{~Hz}, \mathrm{C} 8-\mathrm{H}), 6.59(1 \mathrm{H}, \mathrm{d}, J=8.4 \mathrm{~Hz}, \mathrm{C} 6-\mathrm{H}), 7.11(1 \mathrm{H}, \mathrm{t}, J=8.0 \mathrm{~Hz}, \mathrm{C} 7-\mathrm{H})$, $7.53(1 \mathrm{H}, \mathrm{s}, \mathrm{N}-\mathrm{H})$; IR (KBr): $3176(\mathrm{NH}), 3074,3005(\mathrm{Ar}-\mathrm{CH}), 2932,2886,2833\left(\mathrm{OCH}_{3}, \mathrm{CH}_{2}\right.$ and $\mathrm{CH}-\mathrm{Fc}), 1683(\mathrm{C}=\mathrm{O}), 1599,1510(\mathrm{C}=\mathrm{C}), 1279,1232(\mathrm{C}-\mathrm{N}), 1166,1103(\mathrm{Cp} \mathrm{C}=\mathrm{C}), 481$, 460 (Fe-Cp); Anal. Calcd. for $\mathrm{C}_{20} \mathrm{H}_{19} \mathrm{FeNO}_{2}$ : C, 66.50; H, 5.30; N, 3.88 . Found: C, 66.21; H, $4.91 ; \mathrm{N}, 3.80$.

4-Ferrocenyl-7-chloro-3,4-dihydroquionlin-2-one (10e-1). Yellow solid, mp 198.8-200.3 ${ }^{\circ} \mathrm{C}$. ${ }^{1} \mathrm{HNMR}\left(400 \mathrm{MHz}, \mathrm{CDCl}_{3}\right): \delta 2.88\left(1 \mathrm{H}, \mathrm{dd}, J=6.8 \mathrm{~Hz}\right.$ and $\left.16.0 \mathrm{~Hz}, \mathrm{C}-3 \mathrm{H}_{\mathrm{a}}\right), 3.03(1 \mathrm{H}, \mathrm{dd}, J=$ $6.0 \mathrm{~Hz}$ and $\left.16.0 \mathrm{~Hz}, \mathrm{C}-3 \mathrm{H}_{\beta}\right), 3.98(1 \mathrm{H}, \mathrm{t}, J=6.4 \mathrm{~Hz}, \mathrm{C} 4-\mathrm{H}), 4.06-4.18(9 \mathrm{H}, \mathrm{m}, \mathrm{Cp}-\mathrm{H}), 6.73(1 \mathrm{H}$, $\mathrm{d}, J=2.0 \mathrm{~Hz}, \mathrm{C} 8-\mathrm{H}), 6.92(1 \mathrm{H}, \mathrm{dd}, J=2.0 \mathrm{~Hz}$ and $8.0 \mathrm{~Hz}, \mathrm{C} 6-\mathrm{H}), 6.99(1 \mathrm{H}, \mathrm{d}, J=8.4 \mathrm{~Hz}, \mathrm{C} 7-\mathrm{H})$, 7.61 (1H, s, N-H); IR (KBr): $3183(\mathrm{NH}), 3090,(\mathrm{Ar}-\mathrm{CH}), 2956,2888,\left(\mathrm{OCH}_{3}, \mathrm{CH}_{2}\right.$ and $\left.\mathrm{CH}-\mathrm{Fc}\right)$, $1684(\mathrm{C}=\mathrm{O}), 1584,1485(\mathrm{C}=\mathrm{C}), 1365,1239(\mathrm{C}-\mathrm{N})$, 1157, 1107 (Cp C = C), 481, 451 (Fe-Cp); Anal. Calcd. for $\mathrm{C}_{19} \mathrm{H}_{16} \mathrm{ClFeNO}$ : C, 62.41; H, 4.41; N, 3.83 . Found: C, 62.54; H, 4.47; N, 3.72.

4-Ferrocenyl-5-chloro-3,4-dihydroquionlin-2-one (10e-2). Yellow solid, mp $>250{ }^{\circ} \mathrm{C}$. ${ }^{1} \mathrm{HNMR}$ $\left(400 \mathrm{MHz}, \mathrm{CDCl}_{3}\right): \delta 2.89\left(1 \mathrm{H}, \mathrm{dd}, J=6.8 \mathrm{~Hz}\right.$ and $\left.16.4 \mathrm{~Hz}, \mathrm{C}-3 \mathrm{H}_{\mathrm{a}}\right), 3.15(1 \mathrm{H}, \mathrm{d}, J=16.4 \mathrm{~Hz}$, $\left.\mathrm{C}-3 \mathrm{H}_{\beta}\right), 4.06-4.44(9 \mathrm{H}, \mathrm{m}, \mathrm{Cp}-\mathrm{H}), 4.48(1 \mathrm{H}, \mathrm{d}, J=6.4 \mathrm{~Hz}, \mathrm{C} 4-\mathrm{H}), 6.60(1 \mathrm{H}, \mathrm{dd}, J=2.4 \mathrm{~Hz}$ and 6.4, C6-H), 7.04-7.09 (2H, m, C7-H and C8-H), 7.72 (1H, s, N-H); IR (KBr): 3195 (NH), 3085, 3058 (Ar-CH), 2979, 2912, $\left(\mathrm{OCH}_{3}, \mathrm{CH}_{2}\right.$ and $\left.\mathrm{CH}-\mathrm{Fc}\right), 1689(\mathrm{C}=\mathrm{O}), 1582,1466(\mathrm{C}=\mathrm{C}), 1376$, 
$1251(\mathrm{C}-\mathrm{N}), 1168,1105$ (Cp C = C), 481, 456(Fe-Cp); Anal. Calcd. for $\mathrm{C}_{19} \mathrm{H}_{16} \mathrm{ClFeNO} \cdot$ 0.3 $\mathrm{H}_{2} \mathrm{O}: \mathrm{C}, 61.50 ; \mathrm{H}, 4.51 ; \mathrm{N}, 3.77$. Found: C, 61.55; H, 4.34; N, 3.63.

4-Ferrocenyl-7,8-dichloro-3,4-dihydroquionlin-2-one (10f). Yellow solid, mp 175.3-176.5 ${ }^{\circ} \mathrm{C}$. ${ }^{1} \mathrm{HNMR}\left(400 \mathrm{MHz}, \mathrm{CDCl}_{3}\right): \delta 2.89\left(1 \mathrm{H}, \mathrm{dd}, J=6.0 \mathrm{~Hz}\right.$ and $\left.16.0 \mathrm{~Hz}, \mathrm{C}-3 \mathrm{H}_{\mathrm{a}}\right), 3.04(1 \mathrm{H}, \mathrm{dd}, J=$ $5.6 \mathrm{~Hz}$ and $\left.16.4 \mathrm{~Hz}, \mathrm{C}-3 \mathrm{H}_{\beta}\right), 3.99(1 \mathrm{H}, \mathrm{t}, J=6.4 \mathrm{~Hz}, \mathrm{C} 4-\mathrm{H}), 4.09-4.21(9 \mathrm{H}, \mathrm{m}, \mathrm{Cp}-\mathrm{H}), 6.92(1 \mathrm{H}$, d, $J=8.0 \mathrm{~Hz}, \mathrm{C} 6-\mathrm{H}), 7.05(1 \mathrm{H}, \mathrm{d}, J=8.0 \mathrm{~Hz}, \mathrm{C} 5-\mathrm{H}), 7.84(1 \mathrm{H}, \mathrm{s}, \mathrm{N}-\mathrm{H})$; IR (KBr): $3195(\mathrm{NH})$, 3132, $3049(\mathrm{Ar}-\mathrm{CH}), 2937,2842,\left(\mathrm{OCH}_{3}, \mathrm{CH}_{2}\right.$ and $\left.\mathrm{CH}-\mathrm{Fc}\right), 1686(\mathrm{C}=\mathrm{O}), 1592,1459(\mathrm{C}=\mathrm{C})$, 1351, 1272 (C-N), 1150, 1105 (Cp C = C), 478, 445(Fe-Cp); Anal. Calcd. for $\mathrm{C}_{19} \mathrm{H}_{15} \mathrm{Cl}_{2} \mathrm{FeNO}$ : C, 57.04; H, 3.78; N, 3.50 . Found: C, 57.08; H, 3.36; N, 3.24.

4-Ferrocenyl-5,8-dimethoxyl-3,4-dihydroquionlin-2-one (10g). Yellow solid, mp 242.1-243.5 ${ }^{\circ} \mathrm{C} .{ }^{1} \mathrm{HNMR}\left(400 \mathrm{MHz}, \mathrm{CDCl}_{3}\right): \delta 2.82\left(1 \mathrm{H}, \mathrm{dd}, J=7.2 \mathrm{~Hz}\right.$ and $\left.16.4 \mathrm{~Hz}, \mathrm{C}-3 \mathrm{H}_{\mathrm{a}}\right), 3.02(1 \mathrm{H}, \mathrm{d}, J$ $\left.=16.4 \mathrm{~Hz}, \mathrm{C}-3 \mathrm{H}_{\beta}\right), 3.77\left(3 \mathrm{H}, \mathrm{s}, \mathrm{OCH}_{3}\right.$ on $\left.\mathrm{C} 8\right), 3.86\left(3 \mathrm{H}, \mathrm{s}, \mathrm{OCH}_{3}\right.$ on $\left.\mathrm{C} 5\right), 4.07-4.36(10 \mathrm{H}, \mathrm{m}$, $\mathrm{Cp}-\mathrm{H}$ and C4-H), $6.45(1 \mathrm{H}, \mathrm{d}, J=8.8 \mathrm{~Hz}, \mathrm{C} 6-\mathrm{H}), 6.63(1 \mathrm{H}, \mathrm{d}, J=8.8 \mathrm{~Hz}, \mathrm{C} 7-\mathrm{H}), 7.74(1 \mathrm{H}, \mathrm{s}$, $\mathrm{N}-\mathrm{H})$; IR (KBr): $3196(\mathrm{NH}), 3080(\mathrm{Ar}-\mathrm{CH}), 2991,2929,2829\left(\mathrm{OCH}_{3}, \mathrm{CH}_{2}\right.$ and $\left.\mathrm{CH}-\mathrm{Fc}\right), 1674(\mathrm{C}$ = O), 1604, 1503 (C = C), 1383, $1262(\mathrm{C}-\mathrm{N})$, 1186, 1093 (Cp C = C), 483, 443(Fe-Cp); Anal. Calcd. for $\mathrm{C}_{21} \mathrm{H}_{21} \mathrm{FeNO}_{3} \cdot 0.2 \mathrm{H}_{2} \mathrm{O}$ : C, 63.88; H, 5.46; N, 3.55. Found: C, 63.62; H, 5.28; N, 3.40 .

4-Ferrocenyl-6,7-dimethoxyl-3,4-dihydroquionlin-2-one (10h). Yellow solid, mp 187.4-188.8 ${ }^{\circ} \mathrm{C} .{ }^{1} \mathrm{HNMR}\left(400 \mathrm{MHz}, \mathrm{CDCl}_{3}\right): \delta 2.79\left(1 \mathrm{H}, \mathrm{d}, J=15.2 \mathrm{~Hz}, \mathrm{C}-3 \mathrm{H}_{\mathrm{a}}\right), 2.99(1 \mathrm{H}, \mathrm{d}, J=15.6 \mathrm{~Hz}$, $\left.\mathrm{C}-3 \mathrm{H}_{\beta}\right), 3.80\left(3 \mathrm{H}, \mathrm{s}, \mathrm{OCH}_{3}\right.$ on $\left.\mathrm{C} 6\right), 3.84\left(3 \mathrm{H}, \mathrm{s}, \mathrm{OCH}_{3}\right.$ on $\left.\mathrm{C} 7\right), 4.15-4.25(10 \mathrm{H}, \mathrm{m}, \mathrm{Cp}-\mathrm{H}$ and C4H), 6.28 (1H, s, C8-H), 6.62 (1H, s, C5-H ), $7.50(1 \mathrm{H}, \mathrm{s}, \mathrm{N}-\mathrm{H})$; IR (KBr): $3202(\mathrm{NH}), 3093$ (Ar$\mathrm{CH}), 2989,2840\left(\mathrm{OCH}_{3}, \mathrm{CH}_{2}\right.$ and $\left.\mathrm{CH}-\mathrm{Fc}\right), 1668(\mathrm{C}=\mathrm{O}), 1623,1520(\mathrm{C}=\mathrm{C}), 1381,1276(\mathrm{C}-\mathrm{N})$, 1200, 1104 (Cp C = C), 495, 478(Fe-Cp); Anal. Calcd. for $\mathrm{C}_{21} \mathrm{H}_{21} \mathrm{FeNO}_{3} \cdot 0.3 \mathrm{H}_{2} \mathrm{O}: \mathrm{C}, 63.59 ; \mathrm{H}$, 5.49; N, 3.53. Found: C, 63.29; H, 5.07; N, 3.25.

4-Ferrocenyl-5,8-dimethyl-3,4-dihydroquionlin-2-one (10i). Yellow solid, mp 226.3-227.5 ${ }^{\circ} \mathrm{C}$. ${ }^{1} \mathrm{HNMR}\left(400 \mathrm{MHz}, \mathrm{CDCl}_{3}\right): \delta 2.16\left(3 \mathrm{H}, \mathrm{s}, \mathrm{CH}_{3}\right.$ on $\left.\mathrm{C} 8\right), 2.45\left(3 \mathrm{H}, \mathrm{s}, \mathrm{CH}_{3}\right.$ on $\left.\mathrm{C} 5\right), 2.85(1 \mathrm{H}, \mathrm{dd}, J$ $=6.4 \mathrm{~Hz}$ and $\left.16.4 \mathrm{~Hz}, \mathrm{C}-3 \mathrm{H}_{\mathrm{a}}\right), 3.11\left(1 \mathrm{H}, \mathrm{d}, J=16.0 \mathrm{~Hz}, \mathrm{C}-3 \mathrm{H}_{\beta}\right), 4.07-4.19(10 \mathrm{H}, \mathrm{m}, \mathrm{Cp}-\mathrm{H}$ and C4-H), 6.77 (1H, d, $J=7.6 \mathrm{~Hz}, \mathrm{C} 6-\mathrm{H}), 6.90(1 \mathrm{H}, \mathrm{d}, J=7.6 \mathrm{~Hz}, \mathrm{C} 7-\mathrm{H}), 7.35(1 \mathrm{H}, \mathrm{s}, \mathrm{N}-\mathrm{H})$; IR (KBr): $3219(\mathrm{NH}), 3080(\mathrm{Ar}-\mathrm{CH}), 2938,2887\left(\mathrm{OCH}_{3}, \mathrm{CH}_{2}\right.$ and $\left.\mathrm{CH}-\mathrm{Fc}\right), 1668(\mathrm{C}=\mathrm{O}), 1580$, $1502(\mathrm{C}=\mathrm{C}), 1381,1232(\mathrm{C}-\mathrm{N}), 1200,1105(\mathrm{Cp} \mathrm{C}=\mathrm{C}), 475$, 454(Fe-Cp); Anal. Calcd. for $\mathrm{C}_{21} \mathrm{H}_{21} \mathrm{FeNO} \cdot 0.4 \mathrm{H}_{2} \mathrm{O}: \mathrm{C}, 68.83 ; \mathrm{H}, 6.00 ; \mathrm{N}, 3.82$. Found: $\mathrm{C}, 68.61 ; \mathrm{H}, 5.52 ; \mathrm{N}, 3.84$.

4-Ferrocenyl-3,4-dihydrobenzo[h]quinolin-2-one (10j). Yellow solid, mp >250 ${ }^{\circ} \mathrm{C} .{ }^{1} \mathrm{HNMR}$ $\left(400 \mathrm{MHz}, \mathrm{CDCl}_{3}\right): \delta 3.02\left(1 \mathrm{H}, \mathrm{dd}, J=5.2 \mathrm{~Hz}\right.$ and $\left.15.6 \mathrm{~Hz}, \mathrm{C}-3 \mathrm{H}_{a}\right), 3.16(1 \mathrm{H}, \mathrm{dd}, J=6.4 \mathrm{~Hz}$ and 16.0 Hz, C-3H $\left.\mathrm{H}_{\beta}\right), 4.12-4.20(10 \mathrm{H}, \mathrm{m}, \mathrm{Cp}-\mathrm{H}$ and $\mathrm{C} 4-\mathrm{H}), 7.29(1 \mathrm{H}, \mathrm{d}, J=8.4 \mathrm{~Hz}, \mathrm{Ar}-\mathrm{H}), 7.46-$ $7.56(3 \mathrm{H}, \mathrm{m}, \mathrm{Ar}-\mathrm{H}), 7.73(1 \mathrm{H}, \mathrm{d}, J=8.4 \mathrm{~Hz}, \mathrm{Ar}-\mathrm{H}), 7.81(1 \mathrm{H}, \mathrm{d}, J=8.0 \mathrm{~Hz}, \mathrm{Ar}-\mathrm{H}), 8.20(1 \mathrm{H}, \mathrm{s}, \mathrm{N}-$ $\mathrm{H})$; IR (KBr): $3215(\mathrm{NH}), 3092(\mathrm{Ar}-\mathrm{CH}), 2930,2895\left(\mathrm{OCH}_{3}, \mathrm{CH}_{2}\right.$ and $\left.\mathrm{CH}-\mathrm{Fc}\right), 1678(\mathrm{C}=\mathrm{O})$, 1571, $1519(\mathrm{C}=\mathrm{C})$, 1372, $1289(\mathrm{C}-\mathrm{N}), 1190,1103(\mathrm{Cp} \mathrm{C}=\mathrm{C}), 485$, 452(Fe-Cp); Anal. Calcd. for $\mathrm{C}_{23} \mathrm{H}_{19}$ FeNO: C, 72.46; H, 5.02; N, 3.67. Found: C, 72.15; H, 4.72; N, 3.62.

$\boldsymbol{N}$-4(nitrophenyl)-3-ferrocenylacrylamide (9k). Red solid, mp 217.3-218.5 ${ }^{\circ} \mathrm{C} .{ }^{1} \mathrm{HNMR}(400$ $\left.\mathrm{MHz}_{\mathrm{CDCl}}\right): \delta 4.19(5 \mathrm{H}, \mathrm{s}, \mathrm{Cp}-\mathrm{H}), 4.47(2 \mathrm{H}, \mathrm{s}, \mathrm{Cp}-\mathrm{H}), 4.53(2 \mathrm{H}, \mathrm{s}, \mathrm{Cp}-\mathrm{H}), 6.11(1 \mathrm{H}, \mathrm{d}, J=$ 
14.8, = CH-C = O), $7.37(1 \mathrm{H}, \mathrm{s}, \mathrm{N}-\mathrm{H}), 7.70(1 \mathrm{H}, \mathrm{d}, J=14.8, \mathrm{Cp}-\mathrm{CH}=), 7.78(2 \mathrm{H}, \mathrm{d}, J=8.8 \mathrm{~Hz}$,

$\mathrm{Ar}-\mathrm{H}), 8.23(2 \mathrm{H}, \mathrm{d}, J=8.8 \mathrm{~Hz}, \mathrm{Ar}-\mathrm{H})$; IR (KBr): $3374(\mathrm{NH}), 3096(\mathrm{Ar}-\mathrm{CH}), 2971,2923\left(\mathrm{OCH}_{3}\right.$, $\mathrm{CH}_{2}$ and $\left.\mathrm{CH}-\mathrm{Fc}\right), 1672(\mathrm{C}=\mathrm{O}), 1619(\mathrm{COCH}=\mathrm{CHFc}), 1596,1503(\mathrm{C}=\mathrm{C}$ of $\mathrm{Ar}), 1341,1247$ (C-N), 1536, 1407 ( $\mathrm{N}=\mathrm{O}), 1189,1107$ (Cp C = C), 483, 473(Fe-Cp); Anal. Calcd. for $\mathrm{C}_{19} \mathrm{H}_{16} \mathrm{FeN}_{2} \mathrm{O}_{3} \cdot 0.1 \mathrm{H}_{2} \mathrm{O}: \mathrm{C}, 60.37 ; \mathrm{H}, 4.32 ; \mathrm{N}, 7.41$. Found: $\mathrm{C}, 60.20 ; \mathrm{H}, 4.30 ; \mathrm{N}, 7.18$.

\section{Acknowledgements}

This work is supported from the Item of Science and Technology of Education Ministry of Fujian Province (JA07017), National Science Foundation of China (Grant No. 20773024) and Important Item of Fujian Province (Grant No. 2010Y0033).

\section{References}

1. Wagner, H.; Seligmann, O.; Chari, M. V.; Wollenweber, E.; Dietz, V.; Donnelly, D. M. X.; Donnelly, M. J. M.; O’Donnelly, B. Tetrahedron Lett. 1979, 20, 4269.

2. Asai, F.; Iinuma, M.; Tanaka, T.; Mizuno, M. Phytochemistry 1991, 30, 3091.

3. Nonaka, G.-I.; Kawahara, O.; Nishioka, I. Chem. Pharm. Bull. 1982, 30, 4277.

4. Iinuma, M.; Tanaka, T.; Mizuno, M.; Katsuzaki, T.; Ogawa, H. Chem. Pharm. Bull. 1989, 37, 1813.

5. Hsu, F.-L.; Nonaka, G.-I.; Nishioka, I.; Chem. Pharm. Bull. 1985, 33, 3142.

6. Takechi, M.; Tanaka, Y.; Takehara, M.; Nonaka, G.-I.; Nishioka, I. Phytochemistry 1985, 24, 2245.

7. Neugebauer, R. C.; Uchiechowska, U.; Meier, R.; Hruby, H.; Valkov, V.; Verdin, E.; Sippl, W.; Jung, M. J. Med. Chem. 2008, 51, 1203.

8. Binot, G.; Zard, S. Z. Tetrahedron Lett. 2005, 46, 7503.

9. Patel, M.; McHugh, R. J.; Cordova, B. C.; Klabe, R. M.; Bacheler, L. T.; Erickson-Viitanen, S.; Rodgers, J. D. Bioorg. Med. Chem. Lett. 2001, 11, 1943.

10. Beadle, C. D.; Boot, J.; Camp, N. P.; Dezutter, N.; Findlay, J.; Hayhurst, L.; Masters, J. J.; Penariol, R.; Walter, M. W. Bioorg. Med. Chem. Lett. 2005, 15, 4432.

11. Gunnewegh, E. A.; Hoefnagel, A. J.; Bekkum, H. V. J. Mol. Catal. A: Chem. 1995, 100, 87.

12. Singh, I.; Prasad, A. K.; Sharma, A. K.; Saxena, R. K.; Olsen, C. E.; Cholli, A. L.; Samuelson, L. A.; Kumar, J.; Watterson, A. C.; Parmar, W. Bioorg. Med. Chem. 2003, 11, 529.

13. Aoki, S.; Amamoto, C.; Oyamada, J. Kitamura, T. Tetrahedron 2005, 61, 9291.

14. Bodet, C.; Epifano, F.; Genovese, S.; Curini, M.; Grenier, D. Eur. J. Med. Chem. 2008, 43, 1612. 
15. Vijayakumar, B.; Pushpa, L.; Gopalpur, N.; Prakash, B. S. J. J. Indian. Chem. Soc. 2005, 82, 922.

16. Jagdale, A. R.; Sudalai. A. Tetrahedron Lett. 2007, 48, 4895.

17. Jagdale, A. R.; Sudalai. A. Tetrahedron Lett. 2008, 49, 3790.

18. Pan, X.-H.; Liu, X.; Zhao, B.-X.; Xie, Y.-S.; Shin, D.-S.; Zhang, S.-L.; Zhao, J.; Miao, J.-Y. Bioorg. Med. Chem. 2008, 16, 9093.

19. Li , K.; Foresee, L. N.; Tunge, J. A. J. Org. Chem., 2005, 70, 2881.

20. Safina, L. Y.; Selivanova, G. A.; Koltunov, K. Y.; Shteingarts, V. D. Tetrahedron Lett. 2009, 50, 5245.

21. Lau, H. H.; Hart, H. J. Org. Chem. 1959, 24, 280.

22. Goldberg, S. I. J. Org. Chem. 1960, 25, 482. 